УДК 159.923 .2

doi: 10.15330/ps.10.1.177-185

\author{
Едуард Балашов \\ Національний університет «Острозька академія» \\ eduard.balashov@oa.edu.ua
}

\title{
МЕТАКОНТТИВНИЙ ДОСВІД ЯК ПЕРЕДУМОВА РОЗВИТКУ САМОРЕГУЛЯЦІЇ НАВЧАЛЬНОЇ ДІЯЛЬНОСТІ СТУДЕНТІВ
}

У статті розглядаються психологічні особливості метакогнітивного досвіду як передумови розвитку саморегульованого навчання студентів. Характеризується метакогнітивний рівень інтелектуальної діяльності, на якому суб'єкт розв'язує об'єктивні протиріччя, щзо виникають в прочесі виконання навчальної діяльності. Виокремлюється метапізнання як процес, щчо передбачає моніторинг, регуляцію $i$ контроль суб'єкта за своєю діяльністю. Автор розглядає важливу роль механізму саморегулячії у процесі саморегульованого навчання. Аналіз доводить, щуо саморегулячія у навчанні відбувається, коли суб'єкт виконує ї̈ головну функцію - цілепокладання, здатний виконувати адекватну мислительну діяльність щзодо моделювання діяльності і результатів, перетворювати власну активність у діяльність згідно зі створеною моделлю, долати на особистісному рівні перешкоди задля досягнення поставлених навчальних иілей.

Теоретичний аналіз наукового доробку показує, щзо саморегуляиія особистості поєднує елементи сочіально-психологічних проявів і самосвідомості особистості, а також залучає їі емочійно-поведінкову, мотиваційно-вольову, когнітивно-інтелектуальну сфери. Виокремлено важливу роль рефлексивної компетентності суб'єкта як метакогнітивного компонента у навчальній діяльності. Відзначено, щзо метакогнітивний досвід є необхідною передумовою формування $і$ розвитку особистісної компетентності суб 'єкта пізнавальної діяльності та підкреслено важливе значення рефлексї розумової діяльності суб 'єкта у иььому прочесі. Автор підкреслює важливість подальших наукових розвідок у дослідженні проблематики метакогнітивного досвіду у контексті саморегульованого навчання, щзо сприятиме комплексній розробиі практично спрямованих програм підвищення ефективності навчальної діяльності студентів, розвитку рефлексивних умінь суб'єкта пізнавальної та інтелектуальної діяльності, структуризаціі комплексу психічних прочесів особистості загалом.

Ключові слова: метакогнітивний досвід, саморегульоване навчання, метакогнітивні процеси, студент.

Постановка проблеми. У наш час стрімких змін у системі вищої освіти, а також появи нових течій у вивченні особистості як найвищої суспільної цінності метакогнітивізм поступово став надзвичайно популярним напрямком серед закордонних учених $\mathrm{i}$ дедалі більше стає предметом досліджень вітчизняних психологів. Вивчення проблеми метакогнітивізму поєднує вивчення різноманітних течій - метакогнітивного навчання, метакогнітивного досвіду, метакогнітивних здібностей, індивідуальних стилів метакогнітивної організації навчання тощо.

Проте, незважаючи на свою очевидну теоретичну і практичну значущість, багато аспектів цієї проблематики у сучасній психологічній науці досліджені вочевидь недостатньо, а загальний рівень іiї освоєння не відповідає рівню ії суспільної і соціокультурної важливості. На нашу думку, це зумовлено такими причинами, як відносно нетривалим періодом розробки цієї проблеми (остання чверть двадцятого століття), що об'єктивно не дозволяє досягти високого рівня наукових розробок. По-друге, метакогнітивізм має свою методологічну особливість, яка дуже часто $є$ основною причиною його критичної оцінки і теоретично обмежує його положення. Ця особливість полягає в тому, що існують деякі відмінності між метакогнітивними дослідженнями та психологічною теорією діяльності, а також цілісним вивченням поведінки суб'єкта цієї діяльності. Очевидно, що положення когнітивної психології відрізняються від положень регулятивної психології, і в результаті «недіяльнісний» аспект вивчення метакогнітивних процесів у сучасній психології спричиняє дещо звужені концептуальні висновки [7; 8]. Водночас недостатнє врахування метакогнітивних процесів у діяльності і регуляції цієї діяльності суттєво погіршує засади дослідження у рамках сучасної психологічної теорії діяльності, наприклад, структури i змісту рефлексивних механізмів, компетентності та рівнів навчальної діяльності, адже саме метакогнітивний досвід забезпечує вирішення навчальних завдань за рахунок пере- 
несення фокусу свідомості до метакогнітивного плану діяльності, в ході чого сам процес розв'язання проблеми стає предметом рефлексивного аналізу [15].

Аналіз попередніх досліджень. Дослідження феномену метакогнітивного досвіду розпочалося психологами порівняно недавно, у 80-х роках минулого століття. Спочатку дослідники виокремлювали метакогнітивний досвід як окрему форму ментального досвіду (напр., Дж. Флейвел). У подальшому його стали розглядати у структурі загального інтелектуального досвіду суб'єкта [8; 13].

М. Холодна запропонувала структурну модель інтелекту, в яку входив метакогнітивний рівень, на якому функціонування ментальних структур забезпечує саморегуляцію розумової діяльності суб'єкта цієї діяльності [17]. Авторка визначає, що цей рівень забезпечує організацію регуляційних процесів особистості та іiі ресурсів, які управляють процесом ухвалення рішень у складних ситуаціях. Цей рівень також дозволяє особистості контролювати процес пізнавальної діяльності за допомогою використання навичок планування, моніторингу і регуляції діяльності, оцінки результатів, аналізу і контролю використання відповідних метакогнітивних механізмів і стратегій тощо. Цю думку підтримала I. Пригіна, яка стверджувала, що рівень організації метакогнітивного досвіду забезпечує різноманітність сприйняття особистістю труднощів та незвичайних ситуацій, які можуть виникати у процесі пізнавальної діяльності [12].

Важлива роль у дослідженнях збагачення метакогнітивного досвіду особистості належить рефлексії. На зв'язок цих психологічних феноменів вказували як іноземні дослідники Д. Деніелс, М. Холодна, С. Савін, В. Пономарьова та ін., так вітчизняні дослідники I. Пасічник, Р. Каламаж, Т. Доцевич, О. Савченко, В. Волошина, Е. Балашов, Т. Довгалюк, О. Ткачук, М. Найдьонов та ін. [1; 2; 4; 5; 10; 11;14;15].

Науковці вважали метакогнітивний досвід необхідною передумовою формування i розвитку особистісної компетентності суб'єкта пізнавальної діяльності та підкреслювали важливе значення рефлексії розумової діяльності у цьому процесі [4]. О. Савін вказував, що розвинутий метакогнітивний досвід особистості спричиняє розвиток і активізацію рефлексивності у діяльності суб'єкта, що дозволяє використовувати складні ментальні моделі. Дослідження усієї системи досвіду особистості, вважає автор, дозволяє розглядати важливість власне інтелектуальної діяльності особистості, а не лише акцентувати зовнішні визначники такої діяльності [13]. Його думку продовжила О. Савченко, яка визначала рефлексивну компетентність як важливий структурний компонент системи метакогнітивного досвіду, який разом зі складовими особистісного потенціалу та формами активності забезпечує високий рівень організації та функціонування цієї системи [14]. Рефлексивність як важливий фактор метакогнітивного досвіду педагогів досліджувала Т. Доцевич [5]. Ми у своєму дослідженні розглядаємо метакогнітивний досвід як передумову успішної саморегуляції у навчальній діяльності особистості.

Феномен саморегуляції особистості став предметом численних студій - як зарубіжних (Б. Циммерман, Д. Шунк, Х. Андраде, П. Пінтріх та ін.), так і вітчизняних (О. Савченко, Р. Каламаж, I. Пасічник та ін.). Особливо популярною стає ця тематика у працях сучасник вітчизняних науковців. Так, І. Галян досліджував сутність саморегуляції як особистісної здатності [3]. І. Пасічник і Р. Каламаж досліджували метапізнання у контексті саморегуляції навчальної діяльності [11]. Д. Усик аналізував вікові особливості саморегуляції поведінки школярів [16]. В. Каламаж вивчає питання проектної діяльності у саморегульованому навчанні [6].

На основі виділених у працях М. Боришевського механізмів саморегуляції Т. Довгалюк розглядає механізми метакогнітивного моніторингу [4]. Т. Кириченко також досліджувала механізми саморегулівної поведінки підлітків і юнаків, зокрема їхні ціннісні орієнтації, мотивацію, потреби досягнення успіху та отримання схвалення, локус контролю [9]. Н. Розумовська обгрунтувала значення метакогнітивного моніторингу, який О. Савченко розглядає як один із проявів метакогнітивних ресурсів [15]. 
У своїх дослідженнях автори відзначають важливу для саморегульованого навчання роль вибору механізму саморегуляції, які повинні включати самооцінку в результаті проведеної мислительної діяльності, суб'єктивну емоційну оцінку діяльності та ії корекцію за необхідності, очікування суб'єкта щодо соціально-психологічних результатів діяльності, проектування образу «Я» в результаті самопізнання. Доведено, що саморегуляція у навчальній діяльності може відбутися, коли суб'єкт виконує її головну функцію цілепокладання, здатний виконувати адекватну мислительну діяльність щодо моделювання діяльності та їі результатів, перетворювати власну активність у діяльність згідно зі створеною моделлю, долати на особистісному рівні перешкоди задля досягнення поставлених навчальних цілей. Саморегульована діяльність має часові межі і може бути тактичною (чіткі часові межі, діяльність протягом короткого проміжку часу, конкретні ситуації і поведінкові дії) та стратегічною (спрямована на особистісні зміни на основі активного перетворення метакогнітивного досвіду щодо оперування внутрішніми резервами, побудову довгострокової ієрархії мотивів, пріоритетизація мотивів та виділення духовних мотивів на найвищому рівні [2].

Теоретичний аналіз наукового доробку доводить, що саморегуляція особистості поєднує елементи соціально-психологічних проявів і самосвідомості особистості, а також залучає іiі емоційно-поведінкову, мотиваційно-вольову, когнітивно-інтелектуальну сфери. Проте, незважаючи на значну кількість досліджень, немає чіткого й однозначного визначення поняття саморегуляції в контексті ефективного саморегульованого навчання студентів.

Метою дослідження $є$ теоретичне визначення психологічних особливостей метакогнітивного досвіду як передумови саморегуляції навчальної діяльності.

Методи дослідження: теоретичний аналіз наявних концептуальних положень щодо феноменів метакогнітивного моніторингу і саморегульованого навчання та виявлення їхньої співвідношення у навчальній діяльності студентів 3ВО.

Виклад основного матеріалу. Засновником метакогнітивного напрямку психологічних досліджень вважається Дж. Флейвел. У 1979 році він дав визначення метакогнітивного досвіду як суб'єктивної реакції людини на власні метакогнітивні процеси, відслідковування своїх метакогнітивних знань, процесів цілепокладання та побудови метакогнітивних стратегій [20].

Автор визнав, що метакогнітивний досвід належить до другого порядку, є складним афективним і когнітивним комплексом, який забезпечує активне включення суб'єкта у різноманітну діяльність. Метакогнітивний досвід у цьому разі сприймається суб'єктом діяльності свідомо, і інші автори вказують на те, що він актуалізує попередній досвід у якості фактичного ресурсу для здобуття інформації, вирішення актуальних навчальних завдань [18]. Згідно з Флейвелом метапізнання може супроводжуватися відчуттям страху, фрустрації, успіху/неуспіху, вмотивованості, задоволення/незадоволення тощо; автор підкреслює тісний взаємозв'язок між метапізнанням і складними афективними реакціями суб'єкта діяльності [19].

У своїх пізніших працях Дж. Флейвел переглянув деякі положення попередніх робіт і розширив свої уявлення щодо особистісних характеристик, наприклад, когнітивне розуміння суб'єктом діяльності своїх цінностей, інтересів, здібностей, установок тощо. Особистісні змінні, на думку автора, дозволяють формувати самооцінку через порівняння себе $з$ іншими. Він зазначає, що метапізнавальні процеси найменше підлягають впливу 3 боку соціокультурного середовища, а індивідуальний досвід суб'єкта формує комплекс очікувань стосовно різноманітних видів життєвих завдань і ситуацій.

Дж. Флейвел також виокремив і охарактеризував трирівневу структуру метакогнітивного досвіду. На першому рівні автор розмістив знання людини про себе, свої життєві завдання і стратегії їхньої реалізації. Другий рівень представлений досвідом, який виконує структурування попереднього досвіду і безпосереднього відстежування недавніх подій. На третьому рівні, власне, відбувається метакогнітивна регуляція діяльності, тобто пошук 
релевантних ресурсів для досягнення цілей. Автор встановив, що ефективність моніторингу діяльності залежить від взаємодії таких компонентів метакогнітивного досвіду, як метакогнітивні знання, цілі, переживання і, власне, діяльність суб’єкта [21].

Автор визначив ситуації, які ініціюють участь метапізнавальних процесів у діяльності. Для цього Флейвел використав такі параметри, як наявність проблемної для суб'єкта діяльності ситуації; увага у цій ситуації акцентується на процесі мислення суб'єкта; суб' єкт має досить багато часу на вирішення проблемної ситуації; у процесі пізнавальної діяльності суб'єкт знаходить багато неузгодженостей.

Пізніше Дж. Флейвел, П. Міллер та С. Міллер запропонували узагальнене визначення конструкту «метакогнітивний досвід», під яким вони розуміли складний афективнокогнітивний комплекс, що забезпечує включеність суб'єкта у різноманітні види діяльності та забезпечує загальну метакогнітивну оцінку цієї діяльності, тобто розуміння чи нерозуміння інформації, суб'єктивну оцінку складності завдання та його актуалізації, рівень успішності чи неуспішності у досягнення цілей тощо [22].

Відомо, що метакогнітивний досвід найкраще формується у нових для суб'єкта діяльності ситуаціях, коли існує невизначеність або ступінь відповідальності занадто високий. Емоційно насичені ситуації розглядаються Флейвелом як істотне джерело метакогнітивного досвіду. Він також виокремив два найважливіші пункти, пов'язані 3 генезою метакогнітивних функцій - усвідомлення себе як суб'єкта цього досвіду, а також усвідомлення важливості часу і самосвідомість. На основі теоретичного дослідження автор розробив практичні програми набуття метакогнітивних знань, в яких врахував такі базові метакогнітивні процеси, як цілепокладання і прогнозування [22].

Ці положення важливі у контексті вивчення феномену саморегульованого навчання студентів. У зарубіжному науковому дискурсі для характеристики цього поняття використовують чималу кількість синонімічних термінів, а саме: «self-regulated learning» (саморегульоване навчання) (M. Martinez-Pons, D. Schunk, S. Tonks, B. Zimmerman); «self-directed learning» (самокероване навчання) (R. Brockett, P. Candy, P. Carr, D. Garrison, G. Grow, R. Hiemstra, M. Knowles, D. Mocker, M. Ponton, G. Spear, K. Washbourne); «self-instructional learning» (самоорієнтоване навчання) (J. Blatt,C. Hughes, K. Hugo); «self-learning» (caмонавчання) (A. Gross, D. Katan); «independent learning / study» (незалежне навчання / дослідження) (M. Derrick, M. Healey); «autonomous learning» (автономне навчання) (B. McCombs, M. Ponton, N. Rhea); «individual learning» (індивідуальне навчання) (A. Burke, G. Caputo, D. Robinson, H. Simon).

Більшість моделей саморегульованого навчання пов'язана 3 метакогнітивними знаннями та процесами метапізнання. Американські учені, наприклад, дослідили і довели, що власний прогрес суб'єкта у виконанні завдань і прогнозуванні успішності діяльності можна оцінити на основі організації моніторингу цієї діяльності, а не лише засобами моніторингу власних дій. У розумінні Б. Ціммермана та Д. Шунка, принцип «саморегульованого навчання» означає володіння студентами способами моніторингу, контролю та регулювання навчання [26]. Згідно з П. Пінтріхом саморегульоване навчання $\epsilon$ процесом, за допомогою якого студенти регулюють свої пізнавальні, метакогнітивні, мотиваційні, вольові та поведінкові процеси [25].

Саморегульоване навчання розглядають в аспекті індивідуального регулювання (когнітивні, метакогнітивні, мотиваційні, емоційні та поведінкові дії, що сприяють адаптації до взаємодії з іншими членами групи), який підкреслює розвиток саморегуляції за сприяння зовнішнього моделювання та зворотного зв'язку; спільного регулювання («coregulation»), що включає інших, як правило, більш досвідчених студентів, однолітків тощо й підкреслює соціальний вплив та обмін через «зону найближчого розвитку»; соціально розподіленого регулювання навчання, що, по суті, є колективним регулюванням цілей, прогресу та завдань, де особисті цілі невіддільні від соціальних цілей і досягаються через соціальну взаємодію [6]. 
Спільним у всіх визначеннях є: процес самостійного здобуття студентом знань, формування вмінь і навичок, необхідних для успішного опанування майбутньої професії; опосередковане управління самостійною діяльністю («за завданнями», «без особистої участі»); самокерування навчанням; необхідність застосування розумових зусиль для досягнення мети, виконання завдань; активність та ініціативність суб'єкта навчання й особиста відповідальність за окреслені навчальні цілі та результати; акцентування уваги на мотивації до самостійного навчання тощо.

У дослідженнях феномену ментального досвіду та структурної моделі інтелекту М. Холодної виділено метальні структури як систему психічних утворень, які у діяльності забезпечують отримання інформації, управління процесами обробки інформації та іiї інтелектуального опрацювання. Рівень ментальних структур включає когнітивний досвід, інтенційний досвід, а також і підрівень під назвою «метакогнітивний досвід», який складається 3 ментальних структур, що здійснюють несвідому регуляції процесів обробки інформації і свідому організацію власної інтелектуальної активності суб'єкта на основі аналізу отриманої інформації. Основною виділяється функція контролю за станом індивідуальних інтелектуальних ресурсів та інтелектуальною діяльністю [17].

До складу метакогнітивного досвіду авторка додає і рефлексивні процеси як інтелектуальний контроль діяльності, які включають такі здібності, як планування, передбачення наслідків рішень, оцінку етапів власної інтелектуальної діяльності, вибір і коригування стратегії власного навчання, інтенсифікацію або сповільнення інтелектуальної діяльності. Моніторинг поточної діяльності суб'єкта повинен виконуватися з метою своєчасного іiї коригування у разі відхилення від запланованої діяльності [18]. Дослідження поведінки суб'єкта діяльності на основі цієї моделі з використанням рівнів функціонування особистісного досвіду використовує О. Савченко [14].

Д. Галперн досліджувала ефективність метакогнітивного моніторингу в навчальній діяльності і заявила, що остання корелює зі здатністю самого суб'єкта діяльності правильно оцінити час і кількість зусиль, які необхідні для виконання завдання, а також зі здатністю організувати адекватний контроль за цієї діяльністю [23]. Важливо, що така здатність до моніторингу власної поточної навчальної діяльності формується протягом набуття суб'єктом досвіду. Вона напевно може покращуватися через усвідомлену цілеспрямовану здатність студентів визначати адекватні поточні завдання, розставляти пріоритети, зосереджувати на них більшу увагу. У такому випадку активізуються метакогнітивні стратегії, які студенти використовують для регуляції власної інтелектуальної діяльності у навчанні [24].

Використання і метакогнітивного моніторингу, і метакогнітивних стратегій у своїй діяльності згідно з положеннями структурної моделі інтелекту пов'язане з розробкою ментальної моделі. Суб'єкт проектує свої очікування щодо остаточного результату згідно 3 виробленими раніше критеріями успішності, і в результаті співставлення з актуальною моделлю ця проекція дозволяє суб'єктові контролювати проміжні результати діяльності та коригувати їх відносно кінцевого результату. Очевидно, що у залежності від отриманих проміжних результатів динамічно змінюється і проекція бажаного кінцевого результату, який постійно модифікується в результаті активної діяльності суб'єкта [1].

Особливо важливим виглядає здатність суб'єкта пізнавальної діяльності до критичної оцінки власних можливостей, здібностей, недоліків, оскільки це подекуди заважає адекватному контролю перебігу пізнавальної діяльності і здатності адаптації до умов навчального чи соцікультурного середовища. Невизначеність середовища створює ситуацію, коли суб'єкт повинен моделювати і прогнозувати різноманітні сценарії розвитку навчальної діяльності, а низькі регуляторні здібності не дозволяють повністю адекватно визначити наслідки діяльності. Це дуже важлива здатність, оскільки саме створення адекватних моделей навчальної діяльності активізує відповідні необхідні інтерпретаційні і метакогнітивні механізми [1]. 
Суб’єкт навчальної діяльності активізує рефлексивні дії, які дозволяють створити функціональні моделі постановки навчальних завдань, реструктурувати їх у разі необхідності, передбачати можливі результати цієї навчальної діяльності, впливати на іiі ефективність та контролювати результативність. Саме через розуміння потенційних варіантів розвитку власної пізнавальної діяльності на основі попереднього досвіду, адекватне критичне ставлення до закономірностей і випадковостей у навчальному процесі, розуміння ефективності попередніх алгоритмів діяльності суб'єкт має можливість впливати на успішність своєї пізнавальної діяльності.

Таким чином, основним у когнітивний парадигмі вважається дослідження і опис метакогнітивних процесів, рефлексивних за своєю природою, що передбачає їхнє глибоке вивчення як однієї з найважливіших складових психіки, яка відповідає за обробку інформації суб'єктом навчальної діяльності. У навчальній діяльність це важливо, оскільки у більшості наукових праць метапізнання розглядається як процес, що включає моніторинг, регуляцію і контроль суб'єкта за своєю діяльністю, і це впливає на ефективність навчання [2].

Висновки та перспективи подальших досліджень. Результати проведеного теоретичного аналізу понять метакогнітивного досвіду та саморегульованого навчання дозволяє стверджувати, що останнім часом метакогнітивний напрямок виокремлюється у один 3 найпопулярніших напрямків психологічного дослідження пізнавальних процесів. Сучасна метакогнітивна психологія складається з низки відносно автономних напрямків дослідження, як-от метакогнітивні функції і механізми навчальної і професійної діяльності, сфери метакогнітивного навчання, структурно-функціональні закономірності метапізнавальних процесів та ін.

Метакогнітивні процеси спрямовані на організацію, координацію, виконання i контроль за когнітивними процесами. Вони допомагають суб'єктові діяльності виконувати базові регулятивні функції як щодо сутності власної пізнавальної діяльності, так i щодо організації їі перебігу. Власне, диференціація цих процесів у наукових студіях і допомогла зародженню у кінці минулого століття та стрімкому розвитку метакогнітивних учень, у тому числі вивченню метакогнітивних процесів та метакогнітивного досвіду.

Теоретичний аналіз наявного наукового доробку доводить, що саморегуляція особистості поєднує елементи соціально-психологічних проявів і самосвідомості особистості, а включає iї емоційно-поведінкову, мотиваційно-вольову, когнітивно-інтелектуальну сфери. Важливого значення у вищому шкільництві набуває вивчення кореляційних зв'язків між метакогнітивним досвідом та саморегуляцією навчальної діяльності студентів, адже усвідомлення важливої ролі саморегуляції у навчальній діяльності призводить до значного підвищення академічної успішності.

Науковці вважають метакогнітивний досвід необхідною передумовою формування і розвитку особистісної компетентності суб'єкта пізнавальної діяльності та підкреслюють важливе значення рефлексії розумової діяльності у цьому процесі. Тому перспективи подальших наукових розвідок вбачаємо у дослідженні проблематики метакогнітивного досвіду в контексті саморегульованого навчання, що, на нашу думку, сприятиме комплексній розробці практично спрямованих програм підвищення ефективності навчальної діяльності студентів, розвитку рефлексії у суб'єктів пізнавальної та інтелектуальної діяльності та структуризації комплексу психічних процесів особистості загалом.

1. Балашов, Е. (2019). Психологічні характеристики метакогнітивного моніторингу у навчальній діяльності студентів. Науковий вісник Херсонського державного університету. Серія «Психологічні науки», $4,64-71$.

2. Балашов, Е. (2019). Теоретичні підходи до вивчення чинників мотивації саморегульованого навчання студентів. Теорія і практика сучасної психології, 2 (1), 10-16.

3. Галян, I. (2015). Психологічний аналіз сутності саморегуляції як особистісної здатності. Збірник наукових праџь: філософія, соиіологія, психологія, 20 (1), 154-160.

4. Довгалюк, Т. (2015). Поняття мислення як метакогнітивного процесу у психологічній науці. Молодий вчений, 10 (25). Частина 2, 184-188. 
5. Доцевич, Т. (2014). Розроблення й апробація опитувальника педагогічної рефлексивності викладача вищої школи. Психологічні перспективи, 23, 99-112.

6. Каламаж, В. (2019). Психологічні чинники ефективності групової проектної діяльності студентів ЗВО у процесі вивчення іноземної мови. Дисертація канд. психол. н.: 19.00.01. Луцьк.

7. Карпов, А., Скитяева, И. (2005). Психология метакогнитивных процессов личности. М.: Институт психологии РАН. логии РАН.

8. Карпов, А. (2004). Психология рефлексивных механизмов деятельности. М.: Институт психо-

9. Кириченко, Т. (2011). Психологічні механізми саморегуляції поведінки підлітків: дис. ... канд. психол. наук: 19.00. 07. Київ. Міленіум.

10. Найдьонов, М. (2008). Формування системи рефлексивного управління в організаціях. К.:

11. Пасічник, І., Каламаж, Р., Августюк, М. (2014). Метакогнітивний моніторинг як регулятивний аспект метапізнання. Наукові записки Національного університету «Острозька академія». Серія «Психологія і педагогіка». Тематичний випуск «Актуальні проблеми когнітивної психології», 28, 3-16.

12. Прыгина, И. (2008). Проявление особенностей когнитивного и метакогнитивного опыта личности в субъективной регуляции деятельности (на примере структуры модели субъективно значимых условий): дис. ... канд. психол. н. : 19.00.01. Казань.

13. Савин, Е. (2004). Понятийный и метакогнитивный опыт как основа интеллектуальной компетентности в научной деятельности. Психологический журнал, 25, 5, 50-69.

14. Савченко, О. (2015). Особистісний досвід як основа розвитку духовності. Збірник наукових прачь: філософія, соиіологія, психологія. 20 (2), 156-163.

15. Савченко, О. (2016). Особливості функціонування рефлексивної компетентності як цілісної системи. Психологічні перспективи, 27, 222-236.

16. Усик, Д. (2015). Психологічні особливості саморегуляції поведінки в старшому дошкільному віці. Збірник наукових пращь: філософія, соџіологія, психологія, 20 (2),108-114.

17. Холодная, М. (1997). Психология интеллекта: парадоксы исследования. М.: «Барс».

18. Холодная, М. (2002). О природе индивидуального ума. М.: ПЕР СЭ.

19. Flavell, J.H. (1981). Cognitive Monitoring. In W. P. Dickinson (Ed.), Children's oral communication skills. New York: Academic Press, 35-60.

20. Flavell, J.H. (1979). Metacognition and cognitive monitoring: a new area of cognitive-developmental inquiry. American Psychologist, Vol. 34(10), 906-911.

21. Flavell J.H. (1987). Speculations about the nature and development of metacognition. In: F.E. Weinert \& R.H. Kluwe (Eds.), Metacognition, Motivation, and Understanding (pp. 21-29). Hillsdale, NJ: Lawrence Erlbaum Associates.

22. Flavell, J.H., Miller, P., \& Miller, S. (1993). Cognitive Development. Third edition. Englewood Cliffs, NJ: Prentice Hall.

23. Halpern, D. (1996). Thinking Critically about Critical Thinking. Mahwah, NJ.: Lawrence Erlbaum Associates.

24. Kluwe, R. H. (1982). Cognitive knowledge and executive control: Metacognition. Animal mind - human mind / In D. R. Griffin (Ed.). New York: Springer-Verlag, 201-224.

25. Pintrich, P. (2000). The role of goal orientation in self-regulated learning. Handbook of Self-Regulation. San Diego, CA: Academic Press, 452-502.

26. Schunk, D. H. \& Zimmerman, B. J. (1994). Self-regulation of learning and performance: Issues and educational applications. Hillsdale, NJ, US: Lawrence Erlbaum Associates, Inc.

\section{REFERENCES}

1. Balashov, E. (2019). Psykholohichni kharakterystyky metakohnityvnoho monitorynhu u navchalnii diialnosti studentiv [Psychological charcteristics of metacognitive monitoring in student learning activities]. Naukovyi visnyk Khersonskoho derzhavnoho universytetu. Seriia «Psykholohichni nauky»[ Scientific Bulletin of Kherson State University. Psychological Sciences Series,], 4, 64-71. (ukr.).

2. Balashov, E. (2019). Teoretychni pidkhody do vyvchennia chynnykiv motyvatsii samorehuliovanoho navchannia studentiv [Theoretical approaches to studying the factors of motivation of student self-regulated learning]. Teoriia i praktyka suchasnoi psykholohii [Theory and Practice of Modern Psychology], 2, 10-16. (ukr.).

3. Halian, I. (2015). Psykholohichnyi analiz sutnosti samorehuliatsii iak osobystisnoi zdatnosti [Psychological analysis of essence of self-regulation as a personal ability]. Zbirnyk naukovykh prats: filosofiia, sotsiolohiia, psykholohiia [Collection of scientific works: philosophy, sociology, psychology], 20 (1), 154-160. (ukr.).

4. Dovhaliuk, T. (2015). Poniattia myslennia iak metakohnityvnoho protsesu u psykholohichnii nautsi [Essence of thinking as a metacognitive process in psychological science]. Molodyi vchenyi [Young scientist], 10 (25), 184-188. (ukr.).

5. Dotsevych, T. (2014). Rozroblennia i aprobatsiia opytuvalnyka pedahohichnoi refleksyvnosti vykladacha vyshchoi shkoly [Designing and approbation of questionnaire of reflexivity of a HEI teacher]. Psykholohichni perspektyvy [Psychological perspectives], 23, 99-112. (ukr.). 
6. Kalamazh, V. (2019). Psykholohichni chynyky efektyvnosti hrupovoi proektnoii diialnosti studentiv ZVO u protsesi vyvchennia inozemnoi movy [Psychological factors of efficiency of group project activities of HEI students during learning foreign language]. Abstract of PhD thesis (Psychol. Sci.; 19.00.01). Lutsk. (ukr.).

7. Karpov, A. \& Skityayeva, I. (2005). Psikhologiia metakognitivnykh protsessov lichnosti [Psychology of metacognitive processes of personality]. M.: Institut psikhologii RAN. (rus.).

8. Karpov, A. (2004). Psikhologiia refleksivnykh mekhanizmov deiatelnosti [Psychology of reflexive mechanisms of activity]. M.: Institut psikhologii RAN. (rus.).

9. Kyrychenko, T. (2011). Psykholohichni mekhanizmy samerohuliatsiji povedimnky pidlitkiv [Psychological mechanisms of self-regulation of adolescences' behaviour] Abstract of PhD thesis (Psychol. Sci. 19.00.07). Kyiv.

10. Naidionov, M. (2008). Formuvannia systemy refleksyvnoho upravlinnia $v$ orhanizatsiiakh [Formation of system of reflexive management in organizations]. K.: Milenium. (ukr.).

11. Pasichnyk, I. Kalamazh, R. \& Avhustiuk, M. (2014). Metakohnityvnyi monitorynh iak rehuliatyvnyi aspect metapiznannia. [Metacognitive experience as regulative aspect of metaknowledge]. Scientific Notes of the National University of Ostroh Academy. Series «Psychology and Pedagogy». Thematic Issue «Actual Problems of Cognitive Psychology», 28, 3-16. (ukr.).

12. Prygina, I. (2008). Proiavleniie osobennostei kognitivnogo I metakognitivnogo opyta lichnosti v subiektivnoi regulatsyi deiatelnosti (na primere struktury modeli subiektivno znachimykh uslovii) [Exhibition of peculiarities of cognitive and metacognitive experience of a personality in subjective activity regulation (on example of the model of subjectively meaningful conditions]. Abstract of PhD thesis (Psychol. Sci. 19.00.01). Kazan. (rus.).

13. Savin, E. (2004). Poniatiinyi i metakognitivnyi opyt kak osnova intellektualnoi kompetentnosti v nauchnoi deiatelnosti [Conceptual and metacognitive experience as a foundation of intellectual competence in scientific activity]. Psikhologicheski zhurnal [Psychological Journal], 25, 50-69. (rus.).

14. Savchenko, O. (2015). Osobystisnyi dosvid iak osnova rozvytku dukhovnosti [Personal experience as a foundation of development of spirituality]. Zbirnyk naukovykh prats: filosofiia, sotsiolohiia, psykholohiia [Collection of scientific works: philosophy, sociology, psychology], 20 (2), 156-163. (ukr.)

15. Savchenko, O. (2016). Osoblyvosti funktsionuvannia refleksyvnoi kompetentnosti iak tsilisnoi systemy [Peculiarities of functioning of reflexive competence as an integrated system]. Psykholohichni perspektyvy [Psychological perspectives], 27, 222-236. (ukr.).

16. Usik, D. (2015). Psykholohichni osoblyvosti samorehuliatsii povedinky u starshomu doshkilnomu vitsi [Psikhological peculiarities of self-regulation of behavior at older pre-school age]. Zbirnyk naukovykh prats: filosofiia, sotsiolohiia, psykholohiia [Collection of scientific works: philosophy, sociology, psychology], 20 (2), 108-114. (ukr.).

17. Kholodnaya, M. (1997). Psikholohiia intellekta: paradoksy issledovaniia [Psychology of intellect; paradoxes or research]. M.: Bars. (rus.).

18. Kholodnaya, M. (1997). O prirode individualnogo uma [On the nature of individual mind]. M.: PER SE. (rus.).

19. Flavell J. H. (1981). Cognitive Monitoring. In W. P. Dickinson (Ed.), Children's oral communication skills. New York: Academic Press, 35-60.

20. Flavell J. H. (1979). Metacognition and cognitive monitoring: a new area of cognitive-developmental inquiry. American Psychologist, Vol. 34(10), 906-911.

21. Flavell, J. H. (1987). Speculations about the nature and development of metacognition. In: F. E. Weinert \& R. H. Kluwe (Eds.), Metacognition, Motivation, and Understanding (pp. 21-29). Hillsdale, NJ: Lawrence Erlbaum Associates.

22. Flavell, J. H., Miller, P., \& Miller, S. (1993). Cognitive Development. Third edition. Englewood Cliffs, NJ: Prentice Hall. Associates.

23. Halpern, D. (1996). Thinking Critically about Critical Thinking. Mahwah, NJ.: Lawrence Erlbaum

24. Kluwe, R. H. (1982). Cognitive knowledge and executive control: Metacognition. Animal mind human mind / In D. R. Griffin (Ed.). New York: Springer-Verlag, 201-224.

25. Pintrich, P. (2000). The role of goal orientation in self-regulated learning. Handbook of Self-Regulation. San Diego, CA: Academic Press, 452-502.

26. Schunk, D. H. \& Zimmerman, B. J. (1994). Self-regulation of learning and performance: Issues and educational applications. Hillsdale, NJ, US: Lawrence Erlbaum Associates, Inc.

\section{Eduard Balashov \\ METACOGNITIVE EXPERIENCE AS A PREREQUISITE FOR DEVELOPMENT OF SELF-REGULATION IN STUDETN LEARNING}

Psychological features of metacognitive experience as prerequisites for the development of student selfregulated learning have been considered in the article. The metacognitive level of intellectual activities, at which the subject solves the objective contradictions arising in the course of own learning activities, have been characterized. Metacognition has been determined as a process, which includes the subject's monitoring, regulation and control 
over own activities. The author has considered an important role of the mechanism of self-regulation in the course of self-regulated learning. The analysis has proved that self-regulation of learning activities occurs when the subject executes its main function - goal-setting; is capable to execute adequate thinking activity on modelling own activities and results; transform own activities in accordance with the created models; overcome obstacles on the personal level for achieving the set goals.

Theoretical analysis of the scientific works has showed that self-regulation of personality combines the elements of social and psychological personal signs and self-consciousness of personality, as well as the personality's emotional-behavioral, motivational-volitional, and cognitive-intellectual spheres. The important role of reflexive competency of a subject as a metacognitive component of learning activities has been determined. Metacognitive experience has been described as a necessary prerequisite for the formation and development of a personality's competence in learning activity, and the importance of reflection of the subject's intellectual activity in this process has been emphasized. The author has determined the importance of further scientific endeavors in studying the issue of metacognitive experience in the context of self-regulated learning. This would contribute to the complex development of practically focused programs for improving student learning activity; developing the reflexive skills of the subject of cognitive and intellectual activities; structuring of the mental processes of a personality in general.

Keywords: metacognitive experience, self-regulated learning, metacognitive processes, student. 